\title{
Pengaruh Kualitas Bumbu Dasar Instan Dan Sambal Instan Terhadap Kepuasan Konsumen Industri Jasa Boga Dan Rumah Tangga Di Kota Bandung
}

\author{
Putri Indah Lestari ${ }^{1}$, Woro Priatini ${ }^{1}$, Wendi Andriatna ${ }^{2}$ \\ ${ }^{1}$ Manajemen Industri Katering, Fakultas Pendidikan Ilmu Pengetahuan Sosial, Universitas \\ Pendidikan Indonesia, Jl. Dr. Setiabudhi No. 229, Bandung 40154, Indonesia \\ ${ }^{2}$ Manajemen Keamanan Makanan, Sekolah Tinggi Farmasi Indonesia, Soekarno-Hatta St \\ No.354, Batununggal, Bandung Kidul, Bandung City, West Java 40266
}

* Koresponding Penulis. E-mail: putriindahlestari@student.upi.edu (Putri Indah Lestari)

\begin{abstract}
Abstrak
Produk instan adalah bentuk inovasi produk yang diciptakan di era modern ini. Karena perubahan gaya hidup, produk instan menjadi salah satu alat alternatif dalam pemenuhan kebutuhan setiap konsumen, baik dari kebutuhan primer maupun kebutuhan tersier. Fenomena yang terjadi adalah, pemenuhan pasokan makanan saat ini sebagian besar berbentuk instan, salah satunya bumbu dasar instan dan produk sambal. Hampir di setiap pasar, baik di pasar tradisional, atau pasar ritel modern, bumbu dasar instan dan produk sambal dapat ditemukan dari berbagai produsen. Suatu perusahaan dituntut untuk menghasilkan produk yang berkualitas untuk memenuhi kebutuhan dan keinginan konsumen, guna menciptakan kepuasan konsumen. Ini bisa bermanfaat bagi kedua belah pihak. Oleh karena itu, penulis berhipotesis bahwa ada hubungan antara kualitas produk dan kepuasan pelanggan. Melalui analisis deskriptif dan verifikatif, penulis dapat menggambarkan bagaimana kualitas bumbu dasar instan dan sambal yang beredar di pasar Kota Bandung, dapat menggambarkan tingkat kepuasan pelanggan industri Katering dan Layanan Rumah Tangga di Kota Bandung, serta keberadaan pengaruh yang signifikan dan positif antara variabel kualitas produk (X) dan variabel kepuasan konsumen $(\mathrm{Y})$. Pengumpulan data dilakukan dengan menyebarkan kuesioner kepada 100 responden dari konsumen industri katering dan rumah tangga di Kota Bandung. Dalam variabel kualitas produk, dimensi daya tarik visual memiliki persentase skor tertinggi $74 \%$ untuk produk bumbu instan instan dan $74,2 \%$ untuk produk sambal instan, sedangkan dimensi rasa memiliki persentase skor terendah $61 \%$ untuk produk bumbu dasar instan dan $60 \%$ untuk produk sambal instan. Sementara itu, untuk variabel kepuasan konsumen, 73,75\% konsumen dari industri Catering dan Rumah Tangga di Bandung telah puas dengan kualitas produk bumbu dasar instan, dan $73,44 \%$ telah puas dengan kualitas produk sambal instan. Berdasarkan hasil penelitian, dapat dilihat bahwa kualitas bumbu dasar instan dan produk sambal yang beredar di pasar Bandung memiliki pengaruh 55,1\% terhadap kepuasan pelanggan industri Katering dan Rumah Tangga di Bandung.
\end{abstract}

Kata Kunci: Kepuasan Konsumen; Kualitas Produk; Bumbu Dasar Instan; Sambal Instan.

\section{Pendahuluan}

Saat ini industri pariwisata menjadi sebuah sektor yang sedang gencar dipromosikan oleh pemerintah. Pada 26 November 2016 (Wardhani, 2016) diberitakan bahwa bahwa Presiden Jokowi menargetkan wisata mancanegara sebesar 20 juta di 2019 mendatang. Kemudian diberitakan juga pada 20 Oktober 2016 (Pratiwi \& Sutrisno, 2016), bahwa pemerintah dongkrak pendapatan negara lewat pariwisata. Menteri Pariwisata Arif Yahya menyatakan, dalam beberapa tahun terakhir, industri pariwisata selalu menempati urutan ke-4 atau ke-5 penghasil devisa bagi negara. Sementara sektor lainnya, seperti minyak dan gas, batu bara, 
karet, dan tekstil yang menempati posisi urutan ke-1 hingga ke-4 cenderung menurun sesuai dengan karakternya sebagai nonrenewable produk. Sektor-sektor itu diyakini akan dapat dilampaui oleh sektor pariwisata pada pengujung 2019, dengan target kunjungan wisman sebesar 20 juta dan wisnus sebesar 275 juta dapat dicapai. Sehingga dapat dikatakan bahwa industry pariwisata Indonesia saat ini sangat berpotensial untuk dikembangkan dan berkontribusi untuk negara. Salah satu kontribusi yang dapat diberikan oleh sektor pariwasata yaitu aspek pembangunan ekonomi dimana dapat berimbas pada peningkatan kesejahteraan masyarakat Indonesia.

Indonesia dikenal sebagai negara beriklim tropis yang kaya akan keanekaragaman sumber daya alam serta budayanya. Negara kepulauan terbesar di dunia yang terdiri dari 5 pulau besar dan 34 provinsi ini tentunya memiliki kebudayaan tiap daerah yang unik dan berbeda. Selain itu, didukung oleh kondisi geografisnya Indonesia memiliki keindahan alam yang sangat menakjubkan. Inilah yang menjadi daya tarik Indonesia sebagai negara tujuan pariwisata.

Upaya mendayagunakan dan memperkenalkan budaya dan sumber daya alam tersebut secara optimal, maka dibutuhkan infrastruktur dan juga akses wisata yang mendukung. Leiper mengemukakan bahwa salah satu sektor penunjang dalam industri pariwisata yaitu sektor akomodasi (the accommodation sector) yang berperan sebagai penyedia tempat tinggal sementara (penginapan) dan pelayanan penyediaan makanan dan minuman (food and beverage) (Pitana \& Diarta, 2009, p. 63). Jadi dapat dikatakan bahwa akomodasi penginapan (hotel, motel guest house, dll) dan juga pelayanan penyedia makanan dan minuman (industri jasa boga katering, restoran, dll) merupakan akomodasi penunjang untuk keberlangsungan kegiatan pariwisata.

Dunia kagum dengan

keanekaragaman kuliner Indonesia dan kekayaan rempah-rempahnya. Dengan berlatarbelakang etnis, budaya, adat istiadat, agama yang beragam, menciptakan berbagai sajian dan cita rasa makanan yang khas. Masakan Indonesia dikenal dengan cita rasanya yang kaya akan bumbu. Bumbu merupakan bahan-bahan yang sengaja ditambahkan pada masakan untuk memperoleh cita rasa makanan yang khas, sehingga menggugah selera (Tobing \& Hadibroto, 2015, p. 13). Banyak orang mengatakan bahwa makanan yang kurang bumbu akan kurang sedap rasanya. Maka dari itu bumbu memiliki peranan penting di dalam masakan Indonesia. Dengan menciptakan satu macam bumbu, kita bisa membuat berbagai macam olahan masakan yang rasanya sealur. Bumbu ini dikenal dengan sebutan bumbu dasar. Bumbu dasar atau bumbu inti terdiri dari empat jenis, yaitu bumbu inti tumis, bumbu inti kuning, bumbu inti putih, dan bumbu inti merah (Aruman, 2014, p. 3). Pada dasarnya bumbu inti tumis dan bumbu inti putih memiliki kesamaan bahan baku, hanya saja untuk bumbu inti putih biasanya menggunakan tambahan kemiri ataupun ketumbar dan sering digunakan untuk masakan berkuah.

Selain bumbu, sambal juga tak kalah penting kehadirannya di dalam kuliner Indonesia sebagai pelengkap hidangan (condiment) dan penggugah selera. Masyarakat Indonesia mengatakan bahwa makan kurang nikmat rasanya jika tak ada sambal.Umumnya, sambal berbahan dasar cabai, garam, tomat, dan terasi yang digerus menjadi satu yang kemudian dimakan sebagai cocolan menu lauk pendampingnya (P. \& Rahayu, 2013, p. 4). Tak hanya terasi, sambal juga dapat ditambahkan dengan bahan lain mengikuti selera si pembuatnya. Setiap sambal memiliki pasangan menu makanannya, seperti untuk sayuran yang 
direbus pada pecel atau gado-gado menggunakan sambal kacang, hidangan nasi menggunakan sambal terasi, sate ataupun ikan bakar menggunakan sambal kecap, dan masih banyak lagi. Disamping itu, sambal juga dapat dikelompokkan berdasarkan proses pembuatannya seperti sambal mentah dan sambal masak.

Seiring berjalannya waktu, fenomena perubahan gaya hidup yang modern membuat masyarakat cenderung menginginkan kepraktisan. Seperti halnya di dalam kegiatan konsumsi dan memasak, kini banyak industri makanan menciptakan bumbu dasar instan dan sambal instan. Para perusahaan tersebut berlomba-lomba untuk menawarkan sambal yang praktis siap santap dan bumbu jadi yang sudah diracik. Bumbu instan biasanya telah diracik dan diberi perasa, dikemas dalam kemasan jar, botol, ataupun plastic kedap udara, praktis tinggal ditambahkan ketika proses pemasakan. Sedangkan sambal instan biasanya sambal yang telah dibuat oleh produsen, lalu diawetkan dan dikemas dalam kemasan botol, jar, ataupun kemasan sachet ekonomis. Keberadaan produk bumbu dasar instan dan sambal instan ini dapat ditemukan baik di pasar tradisional maupun ritel modern. Berikut daftar produsen dan jenis produk bumbu dasar instan dan sambal instan yang penulis temukan di berbagai ritel modern (Borma, Junction 8, Papaya, dan Setiabudi Market) di Kota Bandung.

Tabel 1. Daftar Produsen Dan Jenis Bumbu

\begin{tabular}{lrl}
\hline No & $\begin{array}{r}\text { Nama } \\
\text { Produsen }\end{array}$ & \multicolumn{1}{c}{ Jenis Bumbu Dasar } \\
\hline 1 & Munik & 1. Bumbu Putih \\
& & 2. Bumbu Merah \\
& & 3. Bumbu Kuning \\
& & 1. Bumbu Inti A (bumbu \\
& & merah) \\
& & 2. Bumbu Inti B (bumbu \\
& Kokita & kung) \\
& & $\begin{array}{l}\text { 3. Bumbu Inti C (bumbu } \\
\text { putih dengan kemiri) }\end{array}$ \\
&
\end{tabular}

\begin{tabular}{|c|c|c|}
\hline No & $\begin{array}{c}\text { Nama } \\
\text { Produsen }\end{array}$ & Jenis Bumbu Dasar \\
\hline & & $\begin{array}{l}\text { Bumbu Inti D (bumbu putih } \\
\text { dominan bawang } \\
\text { putih) }\end{array}$ \\
\hline
\end{tabular}

Berdasarkan Tabel 1 diketahui bahwa penulis menemukan dua produsen bumbu dasar instan yang beredar di pasar Kota Bandung., yaitu produsen Munik yang memiliki tiga jenis produk bumbu dasar instan, dan produsen Kokita memiliki empat jenis produk bumbu dasar instan.

Tabel 2. Daftar Produsen Dan Jenis Sambal

\begin{tabular}{|c|c|c|}
\hline No & $\begin{array}{c}\text { Nama } \\
\text { Produsen }\end{array}$ & $\begin{array}{c}\text { Jenis Sambal khas } \\
\text { Indonesia }\end{array}$ \\
\hline \multirow[t]{3}{*}{1} & \multirow[t]{3}{*}{ Mertua } & $\begin{array}{l}\text { 1.Sambal Bawang } \\
\text { Level 1-5 } \\
\text { 2. Sambal Ebi }\end{array}$ \\
\hline & & 3. Sambal Teri \\
\hline & & 1. Sambal bajak \\
\hline 2 & Marin & $\begin{array}{l}\text { 2. Sambal Teri } \\
\text { Bawang } \\
\text { 3. Sambal Bawang }\end{array}$ \\
\hline 3 & Kiki & $\begin{array}{l}\text { 1. Sambal Asli } \\
\text { Lampung }\end{array}$ \\
\hline 4 & $\begin{array}{l}\text { Cap Bunga } \\
\text { Teratai }\end{array}$ & 1. Sambal Lampung \\
\hline 5 & $\begin{array}{l}\text { Sambal Cawit } \\
\text { Joosss! }\end{array}$ & $\begin{array}{l}\text { 1. Sambal Cabe } \\
\text { Rawit Level 1-5 }\end{array}$ \\
\hline 6 & Pangestu & $\begin{array}{l}\text { 1. Sambal Ikan } \\
\text { Jambal Roti } \\
\text { 1. Sambal Rawit Ijo }\end{array}$ \\
\hline \multirow[t]{7}{*}{7} & KOKITA & 2. Sambal Bajak \\
\hline & & 3. Sambal Gilaaa \\
\hline & & 4. Sambal Terasi \\
\hline & & 5. Sambal Tauco \\
\hline & & 6. Sambal Oelek \\
\hline & & 7. Sambal Balado \\
\hline & & 8. Kecap Sambal \\
\hline \multirow{3}{*}{8} & \multirow{3}{*}{ Indofood } & 1. Sambal Hijau \\
\hline & & 2. Sambal Balado \\
\hline & & 3. Sambal Terasi \\
\hline 9 & Sasa & 1. Sambal Terasi \\
\hline \multirow{2}{*}{10} & Mariza & 1. Sambal Teri \\
\hline & & $\begin{array}{l}\text { 2. Sambal Udang } \\
\text { Petai Keriting }\end{array}$ \\
\hline
\end{tabular}




\begin{tabular}{|c|c|c|}
\hline No & $\begin{array}{c}\text { Nama } \\
\text { Produsen }\end{array}$ & $\begin{array}{c}\text { Jenis Sambal khas } \\
\text { Indonesia }\end{array}$ \\
\hline & Tosari & $\begin{array}{l}\text { 1. Sambal Bawang } \\
\text { Bodas }\end{array}$ \\
\hline & Munik & $\begin{array}{l}\text { 1. Sambal Bajak } \\
\text { 1. Sambal Terasi }\end{array}$ \\
\hline
\end{tabular}

13 Uleg

$\begin{array}{ll} & \text { 2. Sambal Hijau } \\ & \text { 3. Sambal Bawang } \\ & \text { 4. Sambal Pedas } \\ & \text { Serbaguna } \\ & \text { 1. Sambal Masak } \\ & \text { (Balado) } \\ & \text { 2. Sambal Terasi } \\ & \text { 3. Sambal Bajak } \\ & \\ & \text { 4. Sambal Hijau } \\ & \text { 1. Sambal Goreng } \\ & \text { 2. Sambal Terasi } \\ & \\ & \text { 3. Sambal Hijau } \\ & \text { 1. Sambal Terasi }\end{array}$

Sumber: Data diolah oleh penulis (2017)

Tabel 2 di atas menginformasikan bahwa ditemukannya enam belas produsen sambal instan dengan berbagai macam jenis sambal yang beredar di pasar Kota Bandung. Hal ini menjelaskan bahwa saat ini telah banyak jenis bumbu dasar instan dan sambal instan yang diproduksi oleh berbagai produsen. Artinya, dengan bermunculan varian produk instan tersebut, menunjukkan juga bahwa banyak konsumen yang mengonsumsinya.

Bumbu dasar instan dan sambal instan ini tentunya mudah didapatkan di pasarpasar. Keberadaan produk instan tersebut tentunya membantu para ibu rumah tangga khususnya yang bekerja karena memiliki waktu yang minim untuk memasak ataupun ibu muda yang kurang berpengalaman di dapur. Selain ibu rumah tangga, industri jasa boga juga terbantu akan kehadiran bumbu dasar instan dan sambal instan karena cepat dan praktis dapat menghemat waktu, tenaga, maupun biaya. Adapun pernyataan tersebut didapatkan dari hasil kuesioner prapenelitian yang penulis lakukan pada Desember 2016.
Tabel 3. Daftar Pertanyaan dan Hasil Prapenelitian Penulis

\begin{tabular}{cl}
\hline No & \multicolumn{2}{c}{ Pertanyaan dan Hasil } \\
\hline 1. & $\begin{array}{l}\text { Responden } \\
\text { instan }\end{array}$
\end{tabular}

Kendala yang Dialami dalam

\begin{tabular}{cccccc}
\multicolumn{2}{c}{ Ya } & \multicolumn{2}{c}{ Tidak } & \multicolumn{2}{c}{ Mungkin } \\
$\mathrm{n}$ & $\%$ & $\mathrm{n}$ & $\%$ & $\mathrm{n}$ & $\%$ \\
69 & $69 \%$ & 10 & $10 \%$ & 21 & $21 \%$ \\
Kendala & yang & Dialami & \multicolumn{2}{c}{ dalam }
\end{tabular}

\begin{tabular}{cccccc} 
Repot & $\begin{array}{c}\text { Tidak } \\
\text { Memiliki } \\
\text { Waktu }\end{array}$ & \multicolumn{2}{c}{$\begin{array}{c}\text { Kurang } \\
\text { mengetahui } \\
\text { Cara } \\
\text { Membuat }\end{array}$} \\
$\mathrm{n}$ & $\%$ & $\mathrm{n}$ & $\%$ & $\mathrm{n}$ & $\%$ \\
43 & $43 \%$ & 35 & $35 \%$ & 22 & $22 \%$
\end{tabular}

3. Alasan Menggunakan Bumbu dasar instan dan sambal instan

\begin{tabular}{cccccc}
\multicolumn{2}{c}{ Murah } & \multicolumn{2}{c}{ Praktis } & \multicolumn{2}{c}{ Enak } \\
$\mathrm{n}$ & $\%$ & $\mathrm{n}$ & $\%$ & $\mathrm{n}$ & $\%$ \\
5 & $5 \%$ & 76 & $76 \%$ & 19 & $19 \%$ \\
\hline Sumber: Data prapenelitian penulis & $(2016)$
\end{tabular}

Tabel di atas dapat diketahui bahwa pada pertanyaan pertama dari 100 responden, sebanyak 69 responden menggunakan bumbu dasar instan dan sambal instan. Ini menunjukkan bahwa masyarakat kini banyak memilih untuk menggunakan produk tersebut. Kemudian pada pertanyaan kedua diinformasikan bahwa sebanyak 43 responden mengalami kerepotan dalam membuat bumbu dan sambal serta menjadi kendala terbesar di samping tidak memiliki waktu dan kurang mengetahui cara dan membuat bumbu dasar dan sambal. Pada pertanyaan ketiga didapatkan informasi bahwa praktis menjadi alasan terbesar masyarakat menggunakan bumbu dasar instan dan sambal instan yaitu sebanyak 76 responden. Lalu rasa enak bumbu dasar instan dan sambal instan menjadi pilihan kedua setelah praktis yaitu sebanyak 19\% atau 19 responden, dan 5\% atau 5 responden yang memilih murah. Sehingga penulis menarik kesimpulan bahwa responden saat ini banyak utama yang sangat dibutuhkan dan penting untuk diperhatikan agar konsumen merasa puas 
dengan keberadaan bumbu dan sambal instan di pasaran.

Dengan banyaknya pilihan produk bumbu dasar instan dan sambal instan dari berbagai perusahaan, maka setiap perusahaan harus memiliki keunggulan dari segi kualitas (mutu) produk. Keunggulan kualitas produk tersebut tentunya harus sesuai dengan kebutuhan dan keinginan konsumen. Kualitas produk menjadi pertimbangan konsumen di dalam keputusan pembelian barang. Dengan adanya kualitas produk yang baik dan sesuai dengan kebutuhan konsumen maka hal tersebut dapat menciptakan kepuasan pelanggan. Menurut Kotler (2002, p. 42), kepuasan pelanggan adalah perasaan senang atau kecewa seseorang yang muncul setelah membandingkan antara persepsi/kesannya terhadap kinerja (hasil produk) dan harapanharapannya. Lalu kepuasan pada penelitian ini diukur dengan penilaian berdasarkan kualitas produk pada bumbu dasar instan dan sambal instan, apakah harapan/ekspektasi konsumen sesuai dengan kenyataan kinerja produk yang diterima dan memberikan nilai kepada konsumen.

Berdasarkan uraian dan hasil prapenelitian di atas, penulis mengindikasi adanya hubungan antara kualitas produk terhadap kepuasan konsumen. Maka dari itu penulis ingin menganalisis spesifikasi kualitas seperti apa yang dibutuhkan dan diinginkan konsumen terhadap produk bumbu dasar instan dan sambal instan guna tercapainya kepuasan konsumen yang positif sesuai dengan ekspektasi. Mengingat bahwa bumbu dan sambal memiliki peranan penting di dalam kegiatan konsumsi bagi masyarakat Indonesia serta sebagai salah satu usaha dalam menjaga dan melestarikan budaya kuliner nusantara.

Tujuan dilakukannya penelitian ini adalah untuk mengetahui adakah pengaruh kualitas produk bumbu dasar instan dan sambal instan terhadap kepuasan konsumen industri jasa boga dan rumah tangga di Kota
Bandung.

\subsection{Pariwisata}

Berdasarkan Undang Undang Republik Indonesia No. 10 pasal 1 tahun 2009 dijelaskan bahwa pariwisata adalah berbagai macam kegiatan wisata dan didukung berbagai fasilitas serta layanan yang disediakan oleh masyarakat, pengusaha, pemerintah, dan Pemerintah Daerah.

Pariwisata adalah suatu perjalanan yang dilakukan untuk sementara waktu, yang diselenggarakan dari suatu tempat ke tempat lain, dengan maksud bukan untuk berusaha (business) atau mencari nafkah di tempat yang dikunjungi, tetapi semata-mata untuk memenuhi keinginan yang beraneka ragam (Yoeti, 1996, p. 116).

Menurut Undang-undang No. 9 Tahun 1990 tentang Kepariwisataan: "Segala sesuatu yang berhubungan dengan wisata termasuk semua penyelenggaraan kegiatan pariwisata".

Menurut Ketetapan MPRS No.1-II Tahun 1996: "Suatu cara untuk memenuhi kebutuhan manusia dalam memberi hiburan rohani dan jasmani setelah beberapa waktu bekerja serta mempunyai modal untuk melihat-lihat daerah lain (pariwisata dalam negeri) atau negara-negara lain (pariwisata luar negeri)".

Menurut Fennel: "Tourism is defined as interrelated system that includes tourists and associated service that are provide and utilized (facilities, attraction, transportation, and accommodation) to aid in their movement" (Pitana \& Diarta, 2009, p. 45). Pitana \& Diarta (2009, pp. 45-46) menyebutkan bahwa ada beberapa komponen pokok yang secara umum disepakati di dalam batasan pariwisata (khususnya pariwisata internasional), yaitu sebagai berikut:

a. Traveler, yaitu orang yang melakukan perjalanan antar dua atau lebih lokalitas.

b. Visitor, yaitu orang yang melakukan 
perjalanan ke daerah yang bukan merupakan tempat tinggalnya, kurang dari 12 bulan, dan tujuan perjalanannya bukanlah untuk terlibat dalam kegiatan untuk mencari nafkah, pendapatan, atau peghidupan di tempat tujuan.

c. Tourist, yaitu bagian dari visitor yang menghabiskan waktu paling tidak satu malam (24 jam) di daerah yang dikunjungi (WTO, 1995).

Kemudian oleh Pitana dan Diarta bahwa semua definisi pariwisata yang dikemukankan selalu mengandung beberapa unsur pokok, yaitu:

a. Adanya unsur travel (perjalanan) yaitu pergerakan manusia dari satu tempat ke tempat lain.

b. Adanya unsur ,tinggal sementarae di tempat yang bukan merupakan tempat tinggal yang biasanya.

c. Tujuan utama dari pergerakan manusia tersebut bukan untuk mencari penghidupan/pekerjaan di tempat yang dituju.

Adapun dari penjelesan di atas dapat disimpulkan bahwa pariwisata merupakan suatu rangkaian kegiatan yang dilakukan oleh seseorang maupun kelompok ke suatu daerah di luar tempat tinggalnya dan menetap di tempat tinggal sementara untuk beberapa waktu, menggunakan menggunakan fasilitas, transportasi, dan akomodasi yang telah disediakan oleh masyarakat setempat, pengusaha dan pemerintah dengan tujuan untuk mencari hiburan.

\subsection{Bumbu Dasar}

Terkait dengan pernyataan Alamsyah mengenai kesukaan masyarakat Indonesia terhadap makanan yang berbumbu, maka bumbu memiliki peranan penting di dalam kuliner Indonesia. Bumbu merupakan suatu komponen penting yang ditambahkan di dalam masakan Indonesia untuk memperkaya cita rasa. Tobing \& Hadibroto (2015, p. 13) memaparkan bahwa pada dasarnya bumbu adalah bahan-bahan yang sengaja ditambahkan pada masakan untuk memperoleh cita rasa makanan yang khas, sehingga menggugah selera makan. Menurut KAMIKOKI (2016, p. 1) bumbu dasar adalah bumbu inti yang bias digunakan untuk beberapa masakan dalam satu alur cita rasa. Bumbu terdiri dari aneka jenis rempah (spices and herbs) yang berasal dari tanaman tertentu, seperti akar, kulit batang, daun, bunga, buah, dan biji yang dapat berfungsi dalam pengobatan, sebagai pemberi rasa dan aroma pada masakan, atau sebagai pengawet dan pewarna makanan.

\section{KAMIKOKI $\quad(2016$, p.2)}

menyatakan secara umum ada beberapa bumbu dasar, yaitu putih, kuning, oranye, dan merah. Namun, bumbu oranye merupakan bumbu variasi yang dihasilkan dari percampuran antara bumbu kuning dan merah. Maka dari itu yang penulis menarik kesimpulan bahwa bumbu dasar Indonesia pada intinya hanya memiliki 3 jenis yaitu bumbu dasar putih, bumbu dasar kuning, dan bumbu dasar merah.

\section{a. Bumbu Putih}

Bumbu putih atau putih kekuningan, seperti digunakan pada terik dan opor, adalah bumbu dasar yang komponen utamanya terdiri atas bawang merah, bawang putih, garam yang diberi tambahan kemiri, ketumbar, serta jintan.

b. Bumbu Kuning

Bumbu kuning merupakan bumbu campuran dari bawang putih, bawang merah, kemiri, kunyit, dengan variasi penggunaan cabe merah. Selain itu bumbu aromatik yang ditambahkan juga bervariasi mulai dari jintan dan mesoyi (untuk bumbu gulai), ketumbar (untuk bumbu kare), atau asam jawa (bumbu rujak). Dalam hal ini sereh, daun salam, lengkuas, serta jeruk purut juga digunakan untuk melengkapi wewangian yang diinginkan. Selain gulai, kare, dan rujak, bumbu ini juga dapat digunakan untuk bumbu ayam goreng, pesmol ikan, atau acar kuning. 
c. Bumbu Merah

Bumbu merah terdiri atas campuran bawang merah, bawang putih, dan cabai merah, dilengkapi dengan daun salam, lengkuas, dan petai. Kombinasi bumbu ini dengan santan menghasilkan kuah warna merah yang pedas (berasal dari cabai merah), dan gurih. Bumbu dasar merah dapat diolah menjadi bumbu sambal goreng, ayam rica-rica, telur bumbu bali, kering tempe, pepes, dan kering kentang.

\subsection{Sambal}

Hampir setiap orang Indonesia pada umumnya menyukai rasa pedas. Sambal merupaka pelengkap dan penyerta hidangan (kondimen) wajib di dalam tradisi makan orang Indonesia. Gardjito (2013, p. 128) mendefinisikan bahwa sambal adalah saus yang dibuat dari cabai yang dihancurkan sehingga keluar airnya dan biasanya ditambahkan bahan-bahan lain seperti garam, cuka, daun jeruk, perasan jeruk, terasi, dan lain-lain. Hampir di setiap daerah di Indonesia memiliki sambal khas karena selera lidah dari masyarakat masing-masing daerah juga berbeda. Seperti orang Minang, cita rasa sambalnya cenderung pedas dan asin. Berbeda dengan masyarakat Jawa Tengah, cita rasa sambalnya cenderung manis dan pedas.

Banyak cara yang dapat dilakukan untuk membuat bumbu atau sambal. Mulai dengan cara tradisional menggunakan coet dan mutu yang terbuat dari batu, kayu, maupun tanah liat dengan mengandalkan tenaga manusia, hingga menggunakan penghalus modern seperti blender, food processor, dan grinder yang lebih praktis. Namun, sebagian masyarakat Indonesia masih meyakini bahwa sambal yang dibuat dengan menggunakan cara tradisional lebih memiliki cita rasa yang sedap dibandingkan dengan menggunakan alat modern.

Di dalam buku Bumbu, Penyedap, dan Penyerta Masakan Indonesia, Murdijati Gardjito (2013, pp. 128-131) mengkategorikan aneka sambal berdasarkan proses pembuatannya yaitu:

a. Sambal Mentah

Sambal yang tidak mengalami proses pemasakan, semua bahan yang dipakai adalah bahan segar. Komponen utama dari sambal mentah selain garam dan cabai adalah terasi bakar, bawang merah, bawang putih, penyegar (cuka, air/irisan buah jeruk/irisan daun jeruk), pemanis berupa gula jawa, gula pasir, dan kecap. Selain bahan penyegar yang disebutkan di atas juga dapat ditambahkan aneka buah-buahan antara lain tomat, belimbing, terong, mangga, kueni, nanas, dan gandaria. Sambal mentah umumnya disajikan untuk mendampingi lauk-pauk dibakar dan digoreng, sayuran rebus serta soto dan rawon.

b. Sambal Masak

Sambal masak adalah sambal yang mengalami proses pengolahan, terdiri atas:

1) Sambal tumis, adalah sambah yang mengalami proses pemasakan dengan menggunakan sedikit minyak. Secara umum sambal tumis lebih legit dan berat dibanding sambal mentah sehingga cocok dikonsumsi bersama berbagai soto dan lauk yang digoreng dan ketupat.

2) Sambal rebus, adalah sambal yang mengalami proses pemasakan dengan direbus bersama santan.

3) Sambal kukus, adalah sambal yang mengalami proses pemasakan dengan dikukus menggunakan uap air. Sambal ini sebagai pendamping sayur bobor dan sayur rebus.

4) Sambal panggang, adalah sambal yang mengalami proses pemanggangansetelah semua bahan diulek dan dicampur jadi satu. Proses pemanggangannya dengan menggulung-gulungkan potongan genteng panas pada sambal hingga sambal menempel pada genteng.

c. Sambal Fermentasi 
Sambal yang mengalami proses fermentasi memiliki rasa yang khas, komponen utama dari sambal fermentasi selain garam dan cabai adalah buah jeruk purut yang telah dikupas kulitnya, dipotong kecil dan difermentasi selama dua hari. Sambal parado yang berasal dari Sumbawa adalah sambal fermentasi asli Indonesia.

\subsection{Kualitas Produk}

Produk merupakan alat pemenuh kebutuhan yang dibeli dan dikonsumsi oleh konsumen. Menurut Kotler dan Armstrong (1997, p. 9) produk adalah segala sesuatu yang dapat ditawarkan kepada pasar untuk diperhatikan, dimiliki, digunakan, atau dikonsumsi sehingga dapat memuaskan keinginan atau kebutuhan, produk dapat mecakup obyek fisik, jasa, orang, tempat,organisasi, dan gagasan.

Produk yang ditawarkan oleh perusahaan tentunya harus memiliki nilai. Nilai tersebut berperan sebagai pengukur apakah barang tersebut berfungsi sesuai dengan biaya telah dikeluarkan oleh konsumen. Nilai bagi pelanggan merupakan perbedaan antara nilai yang dinikmati pelanggan karena memiliki serta menggunakan suatu produk dan biaya untuk memiliki produk tersebut (Kotler \& Armstrong, 1997, p. 10).

Untuk mendapatkan nilai bagi pelanggan, suatu produk harus memiliki kualitas. Kualitas produk juga berpengaruh dalam keputusan pembelian konsumen karena dari kualitas produk, konsumen dapat mengetahui sejauh mana produk mampu memenuhi kebutuhan konsumen. Adapun kualitas produk menurut Tjiptono \& Chandra (2007, pp. 130-131) adalah sebagai berikut:
a. Kinerja (performance) karakteristik operasi pokok dari produk inti (core product) yang dibeli.
b. Fitur atau cirri-ciri tambahan (features), yaitu karakteristik sekunder atau pelengkap.

c. Reliabilitas (reliability), yaitu kemungkinan kecil akan mengalami kerusakan atau gagal dipakai.

d. Kesesuaian dengan spesifikasi (conformance to specifications), yaitu sejauh mana karakteristik desain dan operasi memenuhi standar-standar yang telah ditetapkan sebelumnya.

e. Daya tahan (durability), berkaitan dengan berapa lama produk tersebut dapat terus digunakan.

f. Serviceability, meliputi kecepatan, kompetensi, kenyamanan, kemudahan direparasi; serta penanganan keluhan secara memuaskan.

g. Estetika, yaitu daya tarik produk terhadap panca indera.

h. Kualitas yang dipersepsikan (perceived quality), yaitu citra dan reputasi produk serta tanggung jawab perusahaan terhadapnya.

Produk yang dimaksud dalam penelitian ini adalah produk berupa makanan. Ketika para konsumen memilih untuk menggunakan produk bumbu dasar atau sambal instan, maka hal utama yang diorientasikan oleh konsumen adalah bagaimana produk tersebut praktis dan mampu memuaskan kegiatan makannya. Untuk memuaskan kegiatan makannya, banyak indikator kualitas yang harus dimiliki oleh produk bumbu dasar dan sambal instan tersebut mulai dari cita rasa, aroma, penampilan, kemudahan

penggunaan, dan lain sebagainya. Marsum (2005, pp. 159-160) ada tujuh dimensi yang harus diperhatikan dalam mutu makanan, yaitu:

a. Flavour (rasa/bau), harus diperhatikan bahwa rasanya harus enak dan baunya pun harus sedap.

b. Consistency (kemantapan; ketetapan), mutu hidangan/menu yang disajikan harus dijaga supaya mantap atau tetap baik, baik mutu, rasa maupun aromanya.

c. Texture/Form/Shape(susunan/bentuk/p 
otongan), Texture atau susunan dapat diartikan sebagai upaya menyusun suatu hidangan yang lengkap yang memperhatikan adanya hidangan:

1) Yang dikunyah baru ditelan: hidangan pembuka

2) Yang langsung ditelan: hidangan sup pada umumnya

3) Yang dikunyah baru ditelan: hidangan utama

4) Yang langsung telan lagi: hidangan penutup, misalnya macam-macam ice cream, pudding, bavarois, dan sebagainya.

Form/shape adalah irisan atau potongan dari makana yang disajikan. Bentuk atau potongan makanan yang disajikan hendaknya bervariasi, tidak boleh monoton untuk segala hidangan, baik pembuka, hidangan utama, maupun hidangan penutup.

d. Nutritional Content (kandungan gizi) Makanan yang disajikan tetap harus diperhatikan kandungan gizinya. Walaupun di dalan Food service industry yang bersifat

komersial penyajian makanan yang diutamakan penampilannya, gizi dinomorduakan, namun tidak berarti bahwa dalam menyususn menu boleh mengabaikan soal gizi ini.

e. Visual Appeal (daya penarik lewat ketajaman mata). Di dalam menyusun menu atau hidangan perlu diperhatikan penampilannya. Hidangan harus diatur, disusun dengan rapi, seni dan baik agar benar-benar menarik sehingga menimbulkan selera makan bagi para tamu.

f. Aromatic Appeal (daya penarik lewat bau harum). Di dalam menyusun suatu hidangan perlu diperhatikan juga aromanya. Makanan yang disajikan harus sedap/harum aromanya sehingga lebih membangkitkan selera makan para tamu.

g. Temperature (suhu). Artinya di dalam menyajikan makanan harus diperhatikan suhunya. Makanan panas harus disajikan dalam keadaan benarbenar panas, dengan piring yang panas. Untuk makanan dingin, harus disajikan dingin dengan piring atau tempat yang dingin pula.

\subsection{Kepuasan Pelanggan}

Setelah konsumen terpenuhi kebutuhannya atas kesesuaian kualitas produk yang didapatkan, atau produk memberikan nilai kepada pelanggan, maka hal tersebut menciptakan adanya kepuasan pelanggan. Menurut Kotler \& Armstrong di dalam buku Dasar-dasar Pemasaran (1997, p. 10), menyatakan bahwa:

"Kepuasan pelanggan adalah sejauh mana anggapan kinerja produk memenuhi harapan pembeli. Bila kinerja produk lebih rendah ketimbang harapan pelanggan, pembelinya tidak puas. Bila prestasi sesuai atau melebihi harapan, pembelinya merasa puas atau amat gembira".

Kotler juga menambahkan bahwa kepuasan adalah perasaan senang atau kecewa seseorang yang muncul setelah membandingkan antara persepsi/kesannya terhadap kinerja (atau hasil) suatu produk dan harapan-harapannya (2002, p. 42). Selain itu, menurut Engel (dalam Tjiptono, 2008, p. 24) mendefinisikan kepuasan pelanggan sebagai evaluasi purnabeli di mana alternatif yang dipilih sekurangkurangnya sama atau melampaui harapan pelanggan, sedangkan ketidakpuasan timbul apabila hasil (outcome) tidak memenuhi harapan. Dari beberapa definisi di atas dapat ditarik kesimpulan bahwa kepuasan pelanggan merupakan penilaian harapan yang sebanding atau melampaui kenyataan/kinerja yang diperoleh konsumen dari produk yang dibeli.

Terciptanya kepuasan pelanggan dapat memberikan manfaat, diantaranya hubungan antara perusahaan dan pelanggannya menjadi harmonis, 
memberikan dasar yag baik bagi pembelian ulang dan terciptanya loyalitas pelanggan, dan membentuk suatu rekomendasi dari mulut ke mulut (word-of-mouth) yang menguntungkan bagi perusahaan (Tjiptono, 2008, p. 24).

Tjiptono (2008, pp. 25-26) menyatakan ada beberapa faktor yang mengacu di dalam mengevaluasi kepuasan pelanggan terhadap produk, yaitu:

a. Kinerja (performance), yaitu karakteristik operasi pokok dari produk inti (core product) yang dibeli.

b. Ciri-ciri atau keistimewaan tambahan (features), yaitu karakteristik sekunder atau pelengkap.

c. Keandalan (reliability), yaitu kemungkinan kecil akan mengalami kerusakan atau gagal dipakai.

d. Kesesuaian dengan spesifikasi (conformance to specifications), yaitu sejauh mana karakteristik desain dan operasi memenuhi standar-standar yang telah ditetapkan sebelumnya.

e. Daya tahan (durability), berkaitan dengan berapa lama produk tersebut dapat terus digunakan.

f. Serviceability, meliputi kecepatan, kompetensi, kenyamanan, mudah direparasi; serta penanganan keluhan yang memuaskan.

g. Estetika, yaitu daya tarik produk terhadap panca indera.

h. Kualitas yang dipersesikan (perceived quality), yaitu citra dan reputasi produk serta tanggung jawab perusahaan terhadapnya.

Selain 8 faktor yang disebutkan Tjiptono di atas, ada unsur lain menurut Alma (2009, pp. 43-44) yang menjadi pertimbangan konsumen dalam motivasi pembelian barang industri dan dapat mempengaruhi kepuasan pelanggan, yaitu:

a. Pelayanan, pelayanan yang diperlukan ialah yang menyangkut masalah teknik, kemudahan mengganti onderdil yang rusak, pengiriman, berbagai macam informasi, dan sebagainya.

b. Harga, para pembeli barang industri sering kali mempertimbangkan masalah harga, karena dalam pemakaian barang itu banyak terjadi bahan terbuang, biaya memproses bahan, biaya kerusakan dan sebagainya.

c. Penghematan, konsumen kadangkadang mencari penghematan dari bahan yang dipakai.

d. Karakteristik konsumen, dibedakan atas berbagai tipe organisasi pembeli, besar distribusinya, lokasi geografisnya.

e. Populasi pembeli, jumlah pembeli barang industri sangat terbatas, dibandingkan dengan barang konsumsi. Akan tetapi kualitas yang mereka beli sangat banyak.

Menurut Irawan (2009, pp. 37-41) faktor-faktor yang menjadi pendorong kepuasan yaitu:

a. Kualitas produk, pelanggan akan merasa puas jika setelah membeli dan menggunakan produk atau jasa tersebut ternyata kualitasnya baik.

b. Harga, untuk pelanggan yang sensitif, biasanya harga murah adalah sumber kepuasan yang penting karena mereka akan mendapatkan value for money yang tinggi, begitu juga sebaliknya. Untuk industri ritel, komponen haarga ini sungguh penting dan kontribusinya terhadap kepuasan relatif besar.

c. Service Quality, sangat bergantung pada tiga hal, yaitu system, teknologi, dan manusia. Faktor manusia memegang kontirbusi sekitar 70\%. Biasanya kepuasan terhadap kualitas pelayanan sulit ditiru dan menjadi nilai tambah bagi sebuah produk atau jasa.

d. Emotional factor, pelanggan akan meras bangga/percaya diri ketika menggunakan produk tersebut, karena adanya emotional value yang diberikan.

Biaya dan Kemudahan, pelanggan 
akan semakin puas apabila produk relatif mudah, nyaman, dan efisien dalam mendapatkan produk atau pelayanan.

\section{Metode Penelitian}

Penelitian ini memiliki dua variable yaitu satu variabel independen dan satu variabel dependen. Variabel independen dalam penelitian ini adalah kualitas produk (X) yang meliputi flavor (X1), consistency (X2), texture/form/shape (X3), nutritional content (X4), visual appeal (X5), aromatic appeal (X6), dan temperature (X7). Sedangkan untuk variabel dependennya (Y) adalah kepuasan konsumen. Aspek dari variabel dependen yang akan diteliti juga seperti kepuasan pelanggan atas kualitas produk, harga dari produk, service quality yang didapatkan, serta biaya dan kemudahan menggunakan atau memeperoleh produk. Objek penelitian ini adalah bumbu dasar dan sambal instan yang beredar di pasar Kota Bandung. Adapun produk yang menjadi objek penelitian ini adalah sebagai berikut:

Tabel 4. Objek Penelitian

\begin{tabular}{lc}
\hline \multicolumn{1}{c}{ Produk Bumbu } & $\begin{array}{c}\text { Produk Sambal } \\
\text { Dasar Instan }\end{array}$ \\
\hline Bumbu dasar merah & Sambal terasi \\
Bumbu dasar putih & Sambal hijau \\
Bumbu dasar kuning & \\
\hline Sumber: Data Penulis 2017 &
\end{tabular}

Responden pada penelitian ini adalah rumah tangga dan industri jasa boga (hotel, restoran, dan katering) di Kota Bandung. Pengumpulan data untuk latar belakang penelitian di mulai dari November 2016 dan pengumpulan data penelitian dimulai dari April 2017. Metode yang digunakan oleh penulis adalah jenis penelitian deskriptif dan verifikatif. Populasi yang digunakan penulis dalam penelitian ini adalah:
Tabel 5. Populasi Penelitian

\begin{tabular}{ccc}
\hline No. & \multicolumn{1}{c}{ Populasi } & Jumlah \\
\hline \multicolumn{3}{c}{ Industri Jasa Boga: } \\
1. $\quad$ - Hotel : 319 & 1.255 \\
& $\bullet \quad$ Katering $: 358$ & \\
2. Restoran : 578 & 657.769 \\
& Rumah Tangga Kota & 659.024 \\
\hline & Total Populasi
\end{tabular}

Jumlah sampel pada penelitian ini adalah sebanyak 100 responden dengan jumlah responden industri jasa boga sebanyak 56 responden (yang terdiri dari konsumen hotel, katering, dan restoran) dan sisanya 44 responden merupakan konsumen rumah tangga.

Hipotesis yang diajukan dalam penelitian ini adalah adanya pengaruh kualitas produk terhadap kepuasan konsumen. Hipotesis tersebut akan diuji dengan menggunakan analisis regresi linear sederhana, uji $\mathrm{F}$, dan uji $\mathrm{T}$.

\section{Hasil dan Pembahasan}

3.1. Tanggapan Responden Mengenai Kualitas Produk

Berikut rekaptulasi tanggapan responden mengenai kualitas produk:

Tabel 6. Rekaptulasi Tanggapan Responden Mengenai Kualitas Produk

\begin{tabular}{lccc}
\hline \multicolumn{1}{c}{$\begin{array}{c}\text { Kualitas } \\
\text { Produk }\end{array}$} & $\begin{array}{c}\text { Jumlah } \\
\text { Skor }\end{array}$ & $\begin{array}{c}\text { Skor } \\
\text { Ideal }\end{array}$ & $\%$ \\
\hline \multicolumn{1}{c}{ Bumbu Dasar Instan } & & \\
Flavour (rasa) & 610 & 1000 & 61 \\
$\begin{array}{l}\text { Consistency } \\
\text { (kemantapan) }\end{array}$ & 326 & 500 & 65,2 \\
$\begin{array}{l}\text { Texture } \\
\text { (bentuk) }\end{array}$ & 356 & 500 & 71,2 \\
$\begin{array}{l}\text { Nutritional } \\
\text { Content } \\
\text { (kandungan gizi) }\end{array}$ & 359 & 500 & 71,8 \\
$\begin{array}{l}\text { Visual Appeal } \\
\text { (kemenarikan } \\
\text { tampilan) }\end{array}$ & 740 & 1000 & 74 \\
$\begin{array}{l}\text { Aromatic Apeal } \\
\text { (aroma) }\end{array}$ & 366 & 500 & 73,2 \\
\hline
\end{tabular}




\begin{tabular}{|c|c|c|c|}
\hline $\begin{array}{l}\text { Kualitas } \\
\text { Produk }\end{array}$ & $\begin{array}{r}\text { Jumlah } \\
\text { Skor }\end{array}$ & $\begin{array}{l}\text { Skor } \\
\text { Ideal }\end{array}$ & $\%$ \\
\hline $\begin{array}{l}\text { Temperature } \\
\text { (suhu) }\end{array}$ & 313 & 500 & 62,6 \\
\hline Jumlah & 3.070 & 4.500 & 68,22 \\
\hline & Inst: & & \\
\hline Flavour (rasa) & 600 & 1000 & 60 \\
\hline $\begin{array}{l}\text { onsistency } \\
\text { kemantapan) }\end{array}$ & 311 & 500 & 62,2 \\
\hline $\begin{array}{l}\text { xture } \\
\text { entuk) }\end{array}$ & 351 & 500 & 70,2 \\
\hline $\begin{array}{l}\text { Nutritional } \\
\text { Content } \\
\text { (kandungan } \\
\text { gizi) }\end{array}$ & 360 & 500 & 72 \\
\hline $\begin{array}{l}\text { isual Appeal } \\
\text { emenarikan } \\
\text { mpilan) }\end{array}$ & 742 & 1000 & 74,2 \\
\hline $\begin{array}{l}\text { omatic Apeal } \\
\text { oma) }\end{array}$ & 342 & 500 & 68,4 \\
\hline $\begin{array}{l}\text { mperature } \\
\text { hu) }\end{array}$ & 370 & 500 & 74 \\
\hline Imlah & 3.076 & 4.500 & 68,35 \\
\hline \multicolumn{4}{|c|}{$\begin{array}{l}\text { Sumber: Data diolah peneliti } 2017 \\
\text { Berdasarkan tabel di atas, dapat } \\
\text { diketahui bahwa dimensi visual appeal } \\
\text { (kemenarikan tampilan) memiliki } \\
\text { persentase tertinggi pada variabel kualitas } \\
\text { produk bumbu dasar instan yaitu sebesar } \\
74 \% \text { (740:1000 x 100\%), dan secara } \\
\text { keseluruhan kualitas produk bumbu dasar } \\
\text { instan dinilai telah baik oleh konsumen } \\
\text { (berdasarkan perhitungan kategori } \\
\text { menggunakan garis kontinum) dengan } \\
\text { persentase } 68,22 \% \text {. Begitu pula dengan } \\
\text { kualitas produk sambal instan, dimensi } \\
\text { visual appeal (kemenarikan tampilan) } \\
\text { memiliki persentase tertinggi yaitu sebesar } \\
74,2 \% \text { (742:1000 x 100\%) dibanding } \\
\text { dimensi lainnya, serta kualitas produk } \\
\text { sambal instan telah dinilai baik oleh } \\
\text { konsumen dengan persentase 68,35\% } \\
\text { (berdasarkan perhitungan kategori } \\
\text { menggunakan garis kontinum). Artinya } \\
\text { kedua produk instan ini mampu menarik } \\
\text { perhatian konsumen dari sisi tampilan } \\
\text { kemasan maupun warna produk di pasaran. } \\
\text { Namun kedua produk instan ini, untuk } \\
\text { dimensi flavor (rasa) memiliki persentase } \\
\text { terendah dibanding } 6 \text { dimensi lainnya yaitu } \\
61 \% \text { untuk produk bumbu dasar instan dan }\end{array}$} \\
\hline
\end{tabular}

$60 \%$ untuk produk sambal instan.

\subsection{Tanggapan Responden Mengenai Kepuasan Konsumen \\ Berikut data rekaptulasi tanggapan responden mengenai kepuasan konsumen:}

Tabel 7. Rekaptulasi Tanggapan Responden Mengenai Kepuasan Konsumen

\begin{tabular}{lccc}
\hline \multicolumn{1}{c}{$\begin{array}{c}\text { Kepuasan } \\
\text { Konsumen }\end{array}$} & $\begin{array}{c}\text { Jumlah } \\
\text { Skor }\end{array}$ & $\begin{array}{c}\text { Skor } \\
\text { Ideal }\end{array}$ & $\%$ \\
\hline $\begin{array}{lccc}\text { Kualitas } \\
\text { Produk }\end{array}$ & 336 & 500 & 67,2 \\
$\begin{array}{l}\text { Harga } \\
\text { Service }\end{array}$ & 346 & 500 & 69,2 \\
$\begin{array}{l}\text { Quality } \\
\text { Biaya dan }\end{array}$ & 712 & 1000 & 71,2 \\
$\begin{array}{l}\text { Kemudahan } \\
\text { Jumlah }\end{array}$ & 1925 & 2500 & 77 \\
$\begin{array}{l}\text { Kualitas } \\
\text { Produk }\end{array}$ & 3.319 & 4.500 & 73,75 \\
$\begin{array}{l}\text { Harga } \\
\text { Service }\end{array}$ & 327 & 500 & 65,4 \\
$\begin{array}{l}\text { Quality } \\
\text { Biaya dan }\end{array}$ & 337 & 500 & 67,4 \\
$\begin{array}{l}\text { Kemudahan } \\
\text { Jumlah }\end{array}$ & 715 & 1000 & 71,5 \\
$\begin{array}{l}\text { Sumber: } \text { Data diolah peneliti } 2017 \\
\text { Bumstan }\end{array}$ & & & \\
& 1926 & 2500 & 77,04 \\
& 3.305 & 4.500 & 73,44 \\
\hline
\end{tabular}

Berdasarkan tabel rekapitulasi tanggapan responden mengenai kepuasan konsumen di atas, dapat diketahui bahwa dimensi biaya dan kemudahan memiliki persentase tertinggi pada variabel kepuasan konsumen terhadap produk bumbu dasar instan yaitu sebesar 77\% (1925:2500 x $100 \%$ ), dan secara keseluruhan konsumen telah puas terhadap produk tersebut (berdasarkan perhitungan kategori menggunakan garis kontinum) dengan persentase $73,75 \%$. Begitu pula dengan kepuasan konsumen terhadap produk sambal instan, dimensi biaya dan kemudahan memiliki persentase tertinggi yaitu sebesar 77,04\% (1926:2500 x 100\%) dibanding dimensi lainnya, serta kepuasan konsumen terhadap sambal instan berada pada kategori puas dengan persentase $73,44 \%$ (berdasarkan perhitungan kategori 
menggunakan garis kontinum). Dari tabel 7 tersebut dapat kita simpulkan bahwa konsumen telah merasa puas terhadap kedua produk instan tersebut, baik produk bumbu dasar instan maupun sambal instan. Artinya, produk tersebut telah mampu memenuhi apa yang diinginkan dan dibutuhkan oleh konsumen meski belum 100\%. Dengan kata lain produk telah diterima baik di pasaran mulai dari segi kualitas produk, harga, service quality, serta biaya dan kemudahannya.

\subsection{Pengaruh Kualitas Produk terhadap Kepuasan Konsumen}

Perasamaan regresi linear sederhana antara kualitas produk terhadap kepuasan konsumen adalah sebagai berikut:

$\mathrm{Y}=\mathrm{a}+\mathrm{bX}$

$\mathrm{Y}=18,063+0,792 \mathrm{X}$

Keterangan:

$\mathrm{Y}=$ Kepuasan Konsumen $\mathrm{a}=$ Konstanta

$\mathrm{b}=$ Koefisien Regresi $\mathrm{X}=$ Kualitas produk

Berdasarkan persamaan regresi di atas, constant sebesar 18,063 menyatakan bahwa jika tidak ada kualitas produk $(\mathrm{X}=0)$, maka kepuasan konsumen 18,063 satu satuan nilai. Koefisien regresi 0,792 satu satuan nilai artinya apabila terjadi peningkatan kualitas produk makan kepuasan konsumen akan meningkat sebesar 0,792 satu atuan nilai dan sebaliknya apabila terjadi penurunan kualitas produk akan menurunkan kepuasan konsumen sebesar 0,792 satu satuan nilai.

Selain analisis regresi linear sederhana, dilakukan juga uji $F$ untuk menguji hipotesis apakah kualitas produk berpengaruh signifikan terhadap kepuasan konsumen dengan menggunakan uji ANOVA dengan membandingkan Fhitung dan Ftabel. Hasil uji $F$ tersebut menunjukkan bahwa Fhitung bernilai 120,193 dan Ftabel bernilai 2,757. Dari perhitungan tersebut dapat diketahui bahwa nilai Fhitung lebih besar daripada Ftabel. yaitu 120,193 $>2,757$ yang artinya kualitas produk mempengaruhi kepuasan konsumen secara signifikan.

Selanjutnya, Uji T korelasi digunakan untuk mengukur tingkat signifikansi antara variabel $\mathrm{X}$ terhadap variabel $\mathrm{Y}$. Nilai Ttabel dapat dihitung dengan df (degree freedom) $=\mathrm{N}-\mathrm{k}$, dimana $\mathrm{N}=100$ (jumlah sampel) dan $\mathrm{k}=2$ (jumlah variabel), maka $\mathrm{df}=100-2$, maka nilai thitung dengan $\mathrm{df}=98$, dan taraf signifikan $10 \%$. Maka didapat nilai Ttabel $=$ 1,661 (dengan menggunakan rumus Excel $=\operatorname{TINV}(0,1,98))$. Sehingga, dapat diartikan bahwa terdapat pengaruh yang signifikan pada variabel kualitas produk $(\mathrm{X})$ terhadap variabel kepuasan pelanggan $(\mathrm{Y})$.

\section{Kesimpulan}

Kualitas produk bumbu dasar instan dan sambal instan cukup baik, hal tersebut dibuktikan dari hasil pengolahan data kualitas produk yang dirasakan responden. Dari tujuh dimensi kualitas produk (makanan) yang telah dijelaskan, dimensi visual appeal (tampilan) mempunyai nilai paling tinggi, sedangkan nilai terendah dimiliki oleh dimensi flavour (rasa).

Konsumen industri jasa boga dan rumah tangga di Kota Bandung secara keseluruhan telah puas. Kepuasan konsumen tersebut meliputi kepuasan pada kualitas produk, harga, service quality, serta biaya dan kemudahan yang dirasakan dari produk bumbu dasar instan dan sambal instan yang beredar pasar di Kota Bandung.

Kualitas produk berpengaruh terhadap kepuasan konsumen industri jasa boga dan rumah tangga di Kota Bandung. Hal ini dibuktikan dari hasil perhitungan analisis didapatkan hasil nilai korelasi (r) kualitas produk terhadap kepuasan konsumen. Hal tersebut menunjukkan bahwa adanya hubungan antara kualitas produk dengan kepuasan konsumen. Sesuai dengan tabel interpretasi koefisien korelasi nilai $r$, koefisien determinasi pada penelitian ini memiliki hubungan yang kuat. Sementara 
menurut perhitungan koefisien, kualitas produk terhadap memiliki pengaruh sebesar $55,1 \%$ terhadap kepuasan konsumen, sedangkan sisanya 44,9 dipengaruhi oleh faktor lain yang tidak diteliti dalam penelitian ini.

\section{Daftar Pustaka}

Alma, B. (2009). Manajemen Pemasaran dan Pemasaran Jasa. Bandung: ALFABETA.

Aruman, S. (2014). Bumbu Inti untuk Berbagai Masakan. Jakarta: Dunia Kreasi.

Gardjito, M. (2013). Bumbu, Penyedap, dan Penyerta Masakan Indonesia. Jakarta: Gramedia Pustaka Utama.

Irawan, H. (2009). 10 Prinsip Kepuasan Pelanggan. Jakarta: PT Elex Media Komputindo.

KAMIKOKI. (2016). 40 Resep Nusantara Praktis dari 5 Bumbu Dasar. Jakarta: PT Gramedia Pustaka Utama.

Kotler, P. (2002). Manajemen Pemasaran (Edisi Milenium). Jakarta: PT Prenhallindo.

Kotler, P., \& Armstrong, G. (1997). Dasardasar Pemasaran. Jakarta: Prenhallindo.

Majelis Permusyawaratan Rakyat. Sementara. 1996. Ketetapan MPRS N0.1-II Tahun 1996. Jakarta: Majelis Permusyarawatan Rakyat Sementara.

P., T. U., \& Rahayu, S. (2013). Resep Sambal Paling Laris. Jakarta: Dunia Kreasi.

Pitana, I. G., \& Diarta, I. K. (2009). Pengantar Ilmu Pariwisata. Yogyakarta: CV. ANDI OFFSET.

Pratiwi, I., \& Sutrisno, D. (2016, Oktober 20). Republika. Retrieved Desember 2010, 2016, from Republika: http://www.republika.co.id/berita/k oran/kesra/16/10/20/ofc3g52dongkrak-pendapatan-lewatpariwisata
Republik Indonesia. 1990. Undang-Undang

No. 9 Tahun 1990 tentang Kepariwisataan. Lembar Negara Republik Indonesia Tahun 1990 Nomor 78. Sekretariat Kabinet RI. Jakarta.

Republik Indonesia. 2009. Undang-Undang No. 10 tahun 2009 tentang Kepariwisataan. Lembaran Negara Republik Indonesia Tahun 2009 Nomor 11. Sekretariat Negara RI. Jakarta.

Tjiptono, F. (2008). Stragtegi Pemasaran. Yogyakarta: CV. ANDI OFFSET.

Tjiptono, F., \& Chandra, G. (2007). Service, Quality, \& Satisfaction.

Yogyakarta: CV ANDI OFFSET. Tobing, H. A., \& Hadibroto, C. (2015).

Dapur Indonesia 300 Resep Masakan Populer Nusantara. Jakarta: Gramedia Pusaka Utama.

WA, Marsum. (2005). Restoran dan Segala Permasalahannya. Yogyakarta: ANDI.

Wardhani, A. (2016, November 26). Liputan6.com. Retrieved Desember 10, 2016, from Liputan6.com: http://lifestyle.liputan6.com/read/26 62531/presiden-jokowi-targetwisman-sebesar-20-juta-di-2019mendatang.

Yoeti, O. A. (1996). Pengantar Ilmu Pariwisata. Bandung: Angkasa Offset. 